\title{
Hormonal Regulation of Stem Cell Proliferation at the Arabidopsis thaliana Root Stem Cell Niche
}

\section{OPEN ACCESS}

Edited by:

Raffaele Dello loio,

Sapienza University of Rome, Italy

Reviewed by:

Renze Heidstra,

Wageningen University and Research,

Netherlands

Yanhai Yin,

lowa State University, United States

*Correspondence:

Elena R. Álvarez-Buylla

elenabuylla@protonmail.com

Specialty section:

This article was submitted to

Plant Development and EvoDevo,

a section of the journal

Frontiers in Plant Science

Received: 12 November 2020 Accepted: 12 January 2021

Published: 03 March 2021

Citation:

García-Gómez ML,

Garay-Arroyo A, García-Ponce B,

Sánchez MP and Álvarez-Buylla ER (2021) Hormonal Regulation of Stem Cell Proliferation at the Arabidopsis

thaliana Root Stem Cell Niche.

Front. Plant Sci. 12:628491.

doi: 10.3389/fpls.2021.628491

\author{
Mónica L. García-Gómez',2, Adriana Garay-Arroyo 1,2, Berenice García-Ponce1, \\ María de la Paz Sánchez ${ }^{1}$ and Elena R. Álvarez-Buylla ${ }^{1,2 *}$
}

'Laboratorio de Genética Molecular, Desarrollo y Evolución de Plantas, Departamento de Ecología Funcional, Instituto de Ecología, Universidad Nacional Autónoma de México, Ciudad de México, Mexico, ${ }^{2}$ Centro de Ciencias de la Complejidad, Universidad Nacional Autónoma de México, Ciudad de México, Mexico

The root stem cell niche (SCN) of Arabidopsis thaliana consists of the quiescent center (QC) cells and the surrounding initial stem cells that produce progeny to replenish all the tissues of the root. The QC cells divide rather slowly relative to the initials, yet most root tissues can be formed from these cells, depending on the requirements of the plant. Hormones are fundamental cues that link such needs with the cell proliferation and differentiation dynamics at the root SCN. Nonetheless, the crosstalk between hormone signaling and the mechanisms that regulate developmental adjustments is still not fully understood. Developmental transcriptional regulatory networks modulate hormone biosynthesis, metabolism, and signaling, and conversely, hormonal responses can affect the expression of transcription factors involved in the spatiotemporal patterning at the root SCN. Hence, a complex genetic-hormonal regulatory network underlies root patterning, growth, and plasticity in response to changing environmental conditions. In this review, we summarize the scientific literature regarding the role of hormones in the regulation of QC cell proliferation and discuss how hormonal signaling pathways may be integrated with the gene regulatory network that underlies cell fate in the root SCN. The conceptual framework we present aims to contribute to the understanding of the mechanisms by which hormonal pathways act as integrators of environmental cues to impact on SCN activity.

Keywords: root stem cell niche, quiescent center, stem cell regulation, gene regulatory networks, plant development, hormonal regulation

\section{INTRODUCTION}

Stem cells (SCs) are undifferentiated cells that can self-renew and produce progeny that replenishes and regenerates the tissues of multicellular organisms (Alvarado and Yamanaka, 2014). The root stem cell niche (SCN) of Arabidopsis thaliana (Arabidopsis hereafter) has a relatively simple structure, a stereotypical number of SCs, and a highly regular pattern of cell divisions (Dolan et al., 1993) (Figure 1A), making it a unique model to characterize the dynamics of SC activity in living organs. The SCN is located at the root apex and consists of the quiescent center (QC) and the stem or initial cells (ICs) (Barlow, 1978; Dolan et al., 1993; Barlow, 1997; Heidstra and Sabatini, 2014). Depending on their position relative to the QC, ICs produce cells that will become part of 
the different tissues of the root (Dolan et al., 1993) (Figure 1A). The cortex/endodermis initials, the provascular initials, and the epidermis and lateral root cap initials produce cells that will populate the meristem, whereas the distal ICs produce cells of the columella (Dolan et al., 1993). The QC cells divide at a much lower rate than the ICs, although the frequency of division increases with the age of the plant (Timilsina et al., 2019). Clonal and time-lapse analyses have shown that QC divisions are asymmetric and replace different sets of ICs at different frequencies (Kidner et al., 2000; Wachsman et al., 2011; CruzRamírez et al., 2013; Rahni and Birnbaum, 2019). Most QC cell divisions are periclinal (Figure 1B), producing two daughter cells that are positioned at different distances from the provascular cells of the root apical meristem (Cruz-Ramírez et al., 2013). The two daughter cells retain the activity of a QC marker for several days, until eventually one cell differentiates into a columella initial (Cruz-Ramírez et al., 2013). This indicates that QC cell divisions are symmetrical and produce identical cells, and that a cell fate asymmetry takes place after the division event. In this scenario, signals from the niche microenvironment might be instructive for this cell fate decision making. For instance, the production of columella initials is an emergent outcome of a system-level mechanism that considers the feedback regulation between the gene regulatory network in each cell and constraints in the expression pattern and intercellular mobility of the transcription factor SHORT ROOT (SHR) (Box 1; GarcíaGómez et al., 2020). The QC cells can also produce other types of ICs (Kidner et al., 2000; Rahni and Birnbaum, 2019); for instance, anticlinal QC divisions produce cortex/endodermis initials (Figure 1B; Rahni and Birnbaum, 2019). The QC cells are considered a reserve of multipotent SCs that can actively divide and replace lost or damaged initials and meristematic cells (Heyman et al., 2014). Interestingly, the root SCN organization in two SC populations with differing proliferative activities and generative potential is common to SCN of plants and animals (Barlow, 1978; Barlow, 1997; Jiang and Feldman, 2005; Li and Clevers, 2010), suggesting that this could be a generic feature of SCN organization.

The frequency of QC cell divisions changes with the developmental age of the seedlings in Arabidopsis and other plant species (Baum et al., 2002; Jiang and Feldman, 2005; Chen et al., 2011; Timilsina et al., 2019) and also shows variation in different Arabidopsis accessions (Aceves-García et al., 2016). Additionally, QC divisions can be stimulated in response to the availability of nutrients (Sánchez-Calderón et al., 2005), upon root meristematic damage and by genotoxic treatments (CruzRamírez et al., 2013; Heyman et al., 2013). Plant hormones can be regulated by developmental and environmental cues at different levels, including metabolism, signaling, crosstalk, and transport, offering potential mechanisms to integrate external information into the regulation of SCN activity. The role of hormones as mediators between these cues and the regulation of SC activity in the root $\mathrm{SCN}$ is likely to be linked to the gene regulatory network that underlies QC identity and activity. In this case, plant hormonal responses could be channeled toward a common regulatory module to regulate the division at the $\mathrm{QC}$ according to the requirements of the plant.
In this review, we summarize current evidence regarding the regulation of QC cell division in the root SCN of Arabidopsis, focusing on how hormones interact with transcriptional regulatory networks implied in QC activity. We recapitulate on the transcription factors that have been identified as important regulators of QC specification; we summarize the information about the mitotic activity of the QC cells under optimal growth conditions, the role of reactive oxygen species (ROS), and several cell cycle components in the quiescence of the QC cells. We then discuss the effects of auxin, cytokinin (CK), brassinosteroids (BRs), and abscisic acid (ABA) on the division of the QC cells and on the expression of cell identity regulators. The existence of recurrent regulatory targets led us to discuss how hormonal responses may be channeled toward the genetichormonal regulatory network that underlies the acquisition of the cell identity and proliferative profiles in the root SCN, and how it can possibly constitute a developmental module to regulate SC activity in response to changing environmental conditions.

\section{GENETIC REGULATORS OF QC CELL IDENTITY IN THE ROOT SCN}

Several transcription factors have been identified as important regulators of QC cell identity; these also play important roles in the establishment of the radial pattern of the root and in the maintenance of the RAM. One of these regulators is the GRAS transcription factor $S H R$ that is expressed in the provascular tissues at the RAM (Figure 2A; Benfey et al., 1993; Scheres et al., 1995; Helariutta et al., 2000). SHR moves to the endodermis, the cortex/endodermis ICs, and the QC (Nakajima et al., 2001), where it induces SCARECROW (SCR) expression (Cui et al., 2007). SCR and SHR form a heterodimer that localizes in the cell

\footnotetext{
BOX 1 | A system-level mechanism regulating the asymmetric division of QC cells.

The QC cells are considered a reserve of multipotent SCs that can produce all cell types in the root (Heyman et al., 2014), yet most QC cell divisions produce columella initials (Cruz-Ramírez et al., 2013). In a recent study, a mathematical model of genetic regulation in the root SCN was used to understand the mechanism behind this biased production of columella (García-Gómez et al., 2020). A perturbation analysis of a genetic regulatory model was used to identify the regulators that can cause cell state transitions in silico

(García-Gómez et al., 2020); this represents the transition from one cell type to another. SHR was identified as a regulator that causes the transition from the QC to the columella initials state and thus as a candidate regulator that could be behind the asymmetric division of the QC cell. The constraints in SHR expression pattern, intercellular mobility, and nuclear retention in the cells of the RAM were studied in a multilevel model that recovered the dynamics reported upon QC cell divisions (Cruz-Ramírez et al., 2013), namely, that a periclinal QC cell division produces two QC cells, which over time develop differences in their intracellular levels of SHR due to their different proximity to the source of SHR. The intracellular SHR levels in each daughter cell are then interpreted by their regulatory networks, and for one daughter cell, this results in a transition to the columella initials state, resulting in asymmetry in cell fate (García-Gómez et al., 2020). The model also predicted that an increase in the availability of SHR causes a shift from asymmetric to symmetric QC cell divisions, increasing the pool of undifferentiated QC cells in the root SCN (García-Gómez et al., 2020).
} 


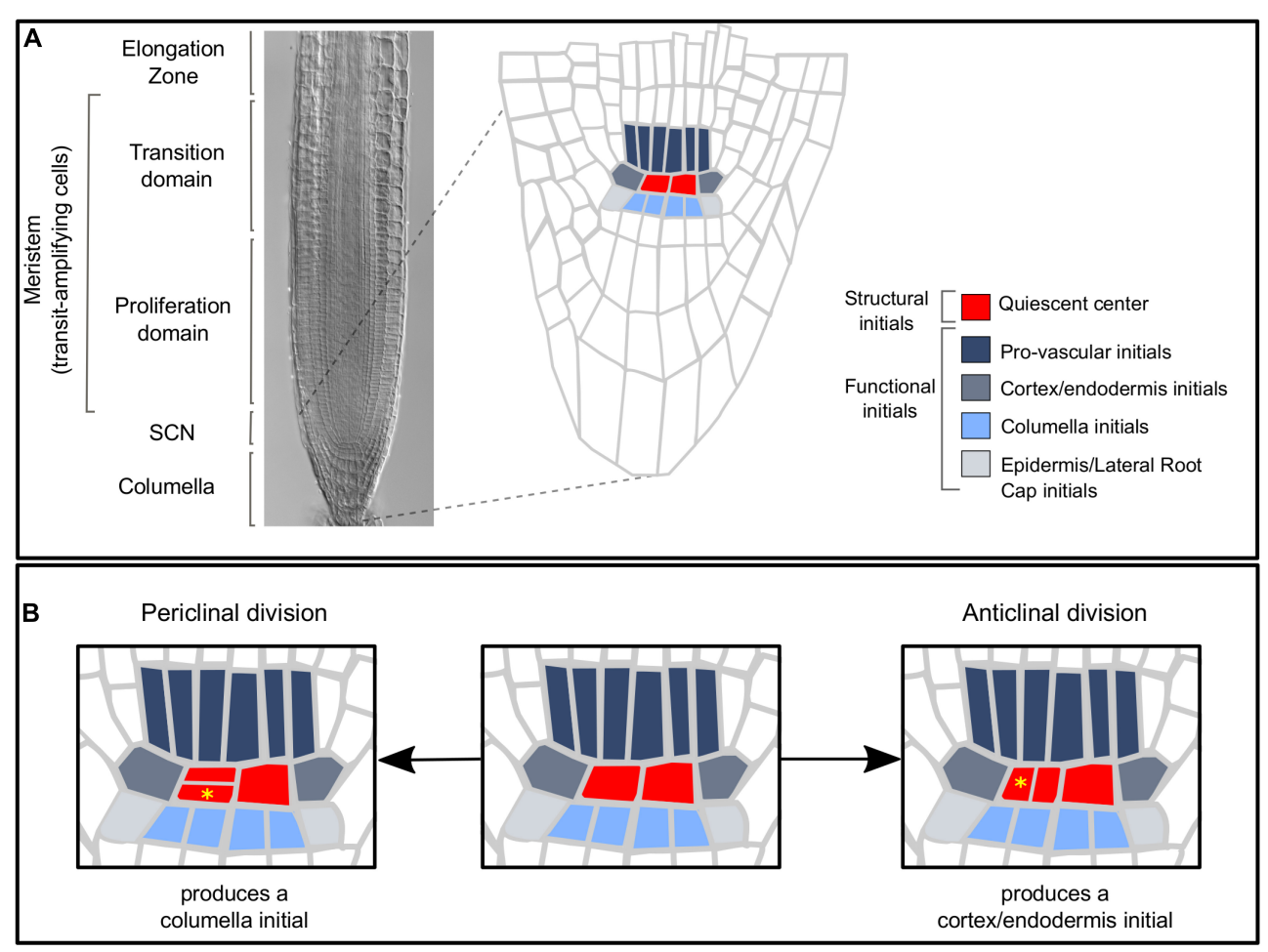

FIGURE 1 | (A) The root apical meristem is composed of the SCN, the proliferation domain, and the transition domain (Ivanov and Dubrovsky, 2013). The SCN houses the QC cells and the ICs [structural and funcional initials, respectively (Barlow, 1997)] which divide asymmetrically and produce cells of different root tissues. The QC cells produce most root tissues and are considered a reserve of multipotent stem cells. (B) QC divisions can be periclinal or anticlinal and produce columella initials or cortex/endodermis initials, respectively. Yellow asterisks mark the daughter cells that replace an initial cell in each case.

nucleus and restricts SHR's intercellular movement (Cui et al., 2007). The SCR/SHR protein complex regulates the expression of genes necessary for the specification of the endodermis, the cortex/endodermis ICs, and the QC cells (Sabatini et al., 2003; Sarkar et al., 2007; Welch et al., 2007; Moreno-Risueno et al., 2015). Additionally, SHR forms heterodimers with JACKDAW (JKD), MAGPIE (MGP), and BLUEJAY (BLJ) transcription factors, forming different protein complexes that localize in the cell nucleus (Long et al., 2015; Long et al., 2017). It has been shown that the endodermis, cortex/endodermis initials, and the QC cells are enriched in different protein complexes containing SHR, SCR, and JKD (Long et al., 2017; Clark et al., 2020), which could be providing specificity in the genes that are regulated by SHR in the different cells of the adjacent layer to the provasculature (Long et al., 2015, 2017; Moreno-Risueno et al., 2015). Loss-of-function mutants in $s c r$ and $s h r$ have defects in the asymmetric division of the cortex/endodermis ICs, and the roots display a single layer of ground tissue (Di Laurenzio et al., 1996). Moreover, these mutants have defects in the specification of the QC and the ICs differentiate, leading to premature consumption of the meristem (Benfey et al., 1993; Sabatini et al., 2003; Sarkar et al., 2007).

The AP2-type PLETHORA transcription factors (PLT1, PLT2, PLT3, and PLT4/BABY BOOM [BBM]) are important regulators for root meristem maintenance (Aida et al., 2004; Galinha et al., 2007; Mähönen et al., 2014). The PLT transcription factors are highly expressed in the cells of the root SCN, including the QC (Figure 2B), and their expression is positively regulated by the high auxin levels in these cells (Aida et al., 2004; Galinha et al., 2007). A protein gradient of PLTs is created along the RAM because of cell growth and proliferation occurring in the meristem, as well as their intercellular movement (Mähönen et al., 2014). In this way, high PLT levels maintain the root SCN, intermediate levels maintain cell proliferation in the meristem, and low levels correlate with the beginning of cell differentiation (Mähönen et al., 2014). In the double-mutant plt1 plt2, the QC cells show defects in the expression of specific QC makers and display QC division events, indicating a loss of QC cell identity and its characteristic quiescent state (Aida et al., 2004).

Another important regulator of the root SCN is WUSCHELrelated homeobox 5 (WOX5), a homeodomain transcription factor that is specifically expressed in the QC cells (Figure 2A; Sarkar et al., 2007). Mutant plants with non-functional WOX5 lack the expression of several QC-specific markers and display differentiation of the distal ICs (Sarkar et al., 2007; Ding and Friml, 2010). The expression of WOX5 depends on the activity of the radial regulators SCR and SHR and the longitudinal PLT regulators mentioned in the previous paragraphs. The scr and $s h r$ mutants lack WOX5 expression and display severe root growth defects (Sarkar et al., 2007), whereas in the case of plt, a multiple mutant has an expanded expression of WOX5 compared to WT plants (Sarkar et al., 2007; Zhai et al., 2020). Recently, it was 
shown that PLT and SCR form a protein complex with teosintebranched cycloidea PCNA (TCP) transcription factor to directly regulate WOX5 expression and the identity of the QC cells (Shimotohno et al., 2018), thus showing a mechanism for the convergence of these regulatory pathways (Figure 2C). Moreover, SCR forms a transcriptional complex with SEUSS (SEU) at the promoter of WOX5 (Figure 2C), in which SEU acts as a scaffold protein that recruits SET DOMAIN GROUP 4 (SDG4), a SET domain methyltransferase (Zhai et al., 2020). The transcriptional complex SCR-SEU-SDG4 is implicated in the deposition of the H3K4me3 epigenetic mark in the promoter of WOX5, critical for its expression and for QC specification (Zhai et al., 2020). SCR expression itself seems to be reduced in seu mutants, suggesting the existence of a positive feedback loop in the regulation of WOX5 in the QC (Zhai et al., 2020).

Auxin is an important regulator of WOX5, and alterations in its distribution, for example, by altering its polar transport, result in the expression of WOX5 in the endodermal cells of the meristem (Sabatini et al., 1999; Mähönen et al., 2014). Auxin signaling regulates WOX5 positively and negatively through different auxin response factors (ARFs): MP (ARF5) is necessary for its expression, whereas ARF10/16 represses it (Sarkar et al., 2007; Ding and Friml, 2010). Interestingly, $M P$ and ARF10 are not expressed homogenously in the RAM (Rademacher et al., 2011), suggesting that the cellular context could be important to define the effect of auxin over WOX5 (García-Gómez et al., 2017). Particularly, $M P$ is expressed in the QC cells but not ARF10 (Rademacher et al., 2011; Truskina et al., 2020), which raises the hypothesis that particular ARF profiles could be important for the auxin regulation of WOX5 expression in these cells. Hence, it is of interest to uncover the mechanisms behind the expression patterns of these ARFs in the RAM in order to understand the specificity of auxin responses in the root meristem; however, there is still no evidence about it. Regulatory links between RAM patterning mechanisms and the auxin signaling components were postulated and put to the test through a mathematical model (García-Gómez et al., 2017). The hypothetical interactions analyzed with the model imply that the heterodimers formed between SHR and its interaction partners JKD and MGP might be involved in the regulation of $M P$ and $A R F 10$, namely, that the SHR-JKD heterodimer represses the expression of ARF10, whereas the SHR-MGP heterodimer represses the expression of $M P$ (García-Gómez et al., 2017). These hypotheses are based on the bioinformatics prediction that SHR represses $A R F 10$ and $M P$ expression (Levesque et al., 2006), on the binding of JKD to the promoter of ARF10 (Moreno-Risueno et al., 2015), and the fact that $A R F 10$ and $J K D$ are expressed on non-overlapping domains in the RAM, and the same for MP and MGP (Welch et al., 2007; Rademacher et al., 2011). The study of these hypothetical interactions in the context of a mathematical regulatory network model of the RAM showed that they are necessary to recover attractors (steady states) with the expression patterns of $M P$ and $A R F 10$, as observed in the cells of the root meristem, including the QC cells (García-Gómez et al., 2017). In the model, the recovered activity configurations allow the expression of WOX5 in the QC cells, but not in the other RAM cells. The results from the model strongly suggest that the expression patterns of the ARF transcription factors define the effect of auxin over WOX5: cells of the RAM with different ARF10 and MP expression profiles will exhibit different auxin responses; some may activate WOX5, whereas other will repress it. The proposed links between patterning mechanisms and hormonal signaling pathways may be critical for understanding how cells will respond to auxin and may constitute a generic mechanism for the spatial specificity of hormonal responses in plant development. Interestingly, it has been shown that the chromatin of several ARFs is constitutively open for transcription, and a series of transcriptional repressors affect their expression (Truskina et al., 2020). Under such a scenario, SHRJKD and SHR-MGP could act as the repressors that are behind the expression patterns of $A R F 10$ and $M P$, respectively, and that underlie the spatial specificity of their activity in the RAM.

Another important regulator of WOX5 is REPRESSOR OF WUSCHEL1 (ROW1), a PHD domain-containing protein that has been shown to restrict WOX5 expression to its characteristic position at the center of the root SCN (Zhang et al., 2015). WOX5 activity in the QC cells is important for the maintenance of the ICs (van den Berg et al., 1997; Ding and Friml, 2010), and in the case of the distal ICs, this is achieved, in part, via the noncellular autonomous activity of WOX5 (Pi et al., 2015). WOX5 moves from the QC cells to the distal ICs where it recruits corepressors and a histone deacetylase to repress the expression of CYCLING DOF FACTOR 4 (CDF4), which promotes the terminal differentiation of the columella cells (Pi et al., 2015). WOX5 also moves toward the provascular initials, where it has been proposed to negatively regulate the expression of $S H R$ (Clark et al., 2020).

\section{CELL CYCLE REGULATION OF THE QC CELLS}

The QC cells divide in optimal growth conditions (Timilsina et al., 2019), albeit at a lower frequency compared to the surrounding ICs and meristematic cells (Wachsman et al., 2011; Cruz-Ramírez et al., 2013). In a pioneering article by Clowes (1956), it was estimated that the QC cells in maize roots display a quarter of DNA synthesis compared to meristematic cells (Clowes, 1956), which is in remarkable accordance to what has been reported for Arabidopsis (Cruz-Ramírez et al., 2013). This similarity in the division frequencies suggests the existence of generic patterns of cell cycle regulation in the root meristem of different plant species.

In Arabidopsis, root growth is not compromised by genetic perturbations that result in alterations in the division patterns of the QC cells, suggesting that low division rate of the QC cells is not strictly necessary for the function and the organization of the root meristem under optimal growth conditions (Vanstraelen et al., 2009; González-García et al., 2011; Cruz-Ramírez et al., 2013; Savina et al., 2020; Wang et al., 2020). The division of the QC cells has been shown to increase in frequency in older Arabidopsis seedlings (Timilsina et al., 2019), and it can also be actively modulated to cope with the current needs of the root. For instance, as a response to changes in hormonal activity, 


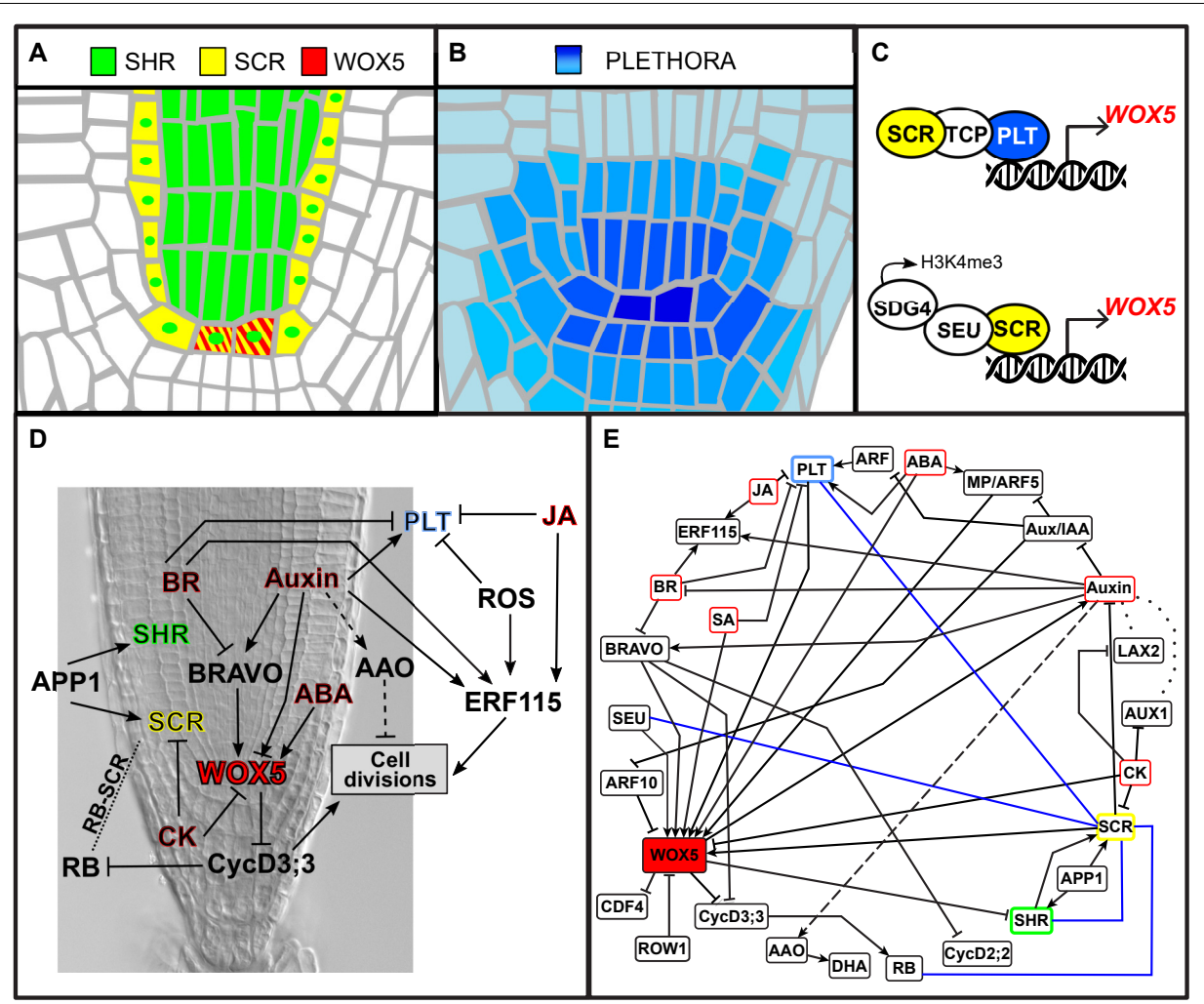

FIGURE 2 | Expression and activity domains of the main genetic regulators of the QC cells fate. In (A), SHR, SCR, and WOX5, and in (B), the PLT family of transcription factors. (C) Protein complexes that bind to the regulatory regions of WOX5 promoter. (D) Schematic representation of some of the regulatory interactions underlying the division of the QC cells. (E) Network depicting the regulatory interactions underlying QC divisions discussed throughout this review. The blue lines indicate protein-protein interactions; dotted lines indicate the role of auxin influx transporters, and the dashed line between auxin and AAO indicates that this particular regulation was observed in maize roots.

limiting phosphate conditions (Sánchez-Calderón et al., 2005), genotoxic treatments that cause cell death of the proliferating cells of the meristem (Cruz-Ramírez et al., 2013; Heyman et al., 2013; Vilarrasa-Blasi et al., 2014), or after the excision of the root cap (Ponce et al., 2005). In the case of QC cell divisions that occur as a response to meristematic damage, it is unknown what noncell-autonomously mechanism is involved in the modulation of QC cell divisions. A potential mechanism to achieve this could be the directional signaling from mature cells of the meristem to the SCs to maintain cell fate (van den Berg et al., 1995), although this possibility requires further investigation.

The regulation of QC cell divisions, as a response to endogenous or environmental signals, must ultimately impact on the activity of the regulators that underlie the progression of the different phases of the cell cycle (Polyn et al., 2015; OrtizGutiérrez et al., 2015). Interestingly, the transcription factor WOX5 directly inhibits the expression of CYD3;3 (Forzani et al., 2014), implying a direct regulatory link between a QC cell fate transcription factor and a regulator of the progression of the cell cycle. D-type cyclins (CYCD) form a complex with A-type cyclin-dependent kinases to regulate the commitment point at G1/S transition through the phosphorylation and inactivation of retinoblastoma-related (RBR) protein, to release
E2F transcriptional factor (Polyn et al., 2015); these are necessary steps for the transition to the $\mathrm{S}$ phase of the cell cycle. Otherwise, RBR activity maintains a quiescent state of the QC cells (Wildwater et al., 2005; Cruz-Ramírez et al., 2013). RBR in the QC maintains its low proliferative state, and consequently seedlings with no RBR activity in the QC display cell divisions (CruzRamírez et al., 2013). This regulation of QC cell proliferation is mediated by the interaction of RBR and SCR (Cruz-Ramírez et al., 2013). Disruption of this interaction yields QC divisions (Cruz-Ramírez et al., 2013), thus establishing a regulatory circuit of cell cycle and cell fate regulators that modulate QC cell divisions. The repression of CYCD3;3 by WOX5 explains the extended G1 phase and low mitotic rate of the QC cells. Interestingly, local expression of $C Y C D 1 ; 1$ and of $C Y C D 3 ; 3$ in the QC using the WOX5 promoter showed that only CYCD3;3 is able to significantly induce cell division in the embryonic QC (Forzani et al., 2014). Additionally, CYCD6;1, which is part of a regulatory circuit that regulates the asymmetric cell division of the cortex/endodermis IC, is not expressed in the QC cells (Sozzani et al., 2010; Cruz-Ramírez et al., 2013). Hence, CYCD proteins might be part of cell type-specific programs of cell cycle regulation, which could underlie the varying proliferation rates in different tissues (de Almeida Engler et al., 2009). 
BOX 2 | Hormone signal transduction basics.

- Auxin

Auxin regulates a high variety of plant developmental processes, including cell proliferation in the root meristem and the maintenance of the root SCN (Sabatini et al., 1999; Ishida et al., 2010). The auxin signaling pathway is composed of the family of ARF and Aux/IAA transcription factors that regulate the expression of auxin-responsive genes (Ulmasov et al., 1999; Okushima et al., 2005; Guilfoyle and Hagen, 2007). The auxin signaling pathway is elicited when the hormone binds to its coreceptors, the transport inhibitor response1/auxin signaling F-box protein1-5 (TIR1/AFB) and its substrates, the Aux/IAA proteins (Dharmasiri et al., 2005; Calderon Villalobos et al., 2012). TIR1/AFB are components of the SKP1/Cullin/F-box protein (SCFTIR1/AFB) ubiquitin ligase complex, and auxin produces a conformational change that favors its interaction with the Aux/IAA proteins, promoting their ubiquitination and eventual degradation (Xu et al., 2007). In this way, auxin frees the ARF transcription factors from the repressive action of AuX/IAA, so that they can regulate the expression of auxin-responsive genes.

Auxin displays a concentration gradient along the longitudinal axis of the root with a maximum at the QC cells (Sabatini et al., 1999; Sarkar et al., 2007; Petersson et al., 2009; Brunoud et al., 2012). This gradient correlates with the cellular activities of the cells along the RAM: the highest auxin concentration is found in the SCN, where cells have low division rates; the proliferation domain has high auxin concentration, and cells divide actively, and then in the transition domain, where auxin levels decrease, and cells stop dividing (Blilou et al., 2005; Mähönen et al., 2014). Auxin distribution in the root is the result of the regulation of auxin metabolism, conjugation, and transport, the latter mediated by efflux and influx proteins that actively move auxin between cells (Petersson et al., 2009; Vanneste and Friml, 2009; Liu et al., 2017). Auxin can enter cells passively and also through the activity of the auxin influx proteins AUX1, LAX1, LAX2, and LAX3, which are expressed in different tissues of the root (Swarup et al., 2005; Péret et al., 2012). The family of PIN-FORMED (PIN) proteins are auxin efflux transporters that play a major role in the generation of auxin distribution patterns throughout development (Blilou et al., 2005). In the root, the PIN efflux transporters are polarly localized in the cell membranes, forming a rootward auxin flux through the vascular tissues. At the columella, PINs redistribute auxin laterally, connecting it with a shootward flux through the outside root tissues (Blilou et al., 2005). This PIN distribution forms a transport network that underlies the distribution of auxin in a gradient with a maximum in the position of the QC cells (Blilou et al., 2005; Grieneisen et al., 2007). The distribution of auxin in the root meristem is tightly regulated and can be modulated by complex mechanisms that regulate PIN expression and PIN localization and the regulation of auxin metabolism that fine-tunes the patterns of auxin accumulation in the cells (Gonzali et al., 2005; Liu et al., 2017).

\section{- Cytokinin}

Plant cells sense CK via a two-component signaling pathway similar to the phosphorelay system found in bacteria (Santner et al., 2009). The CK receptors, Arabidopsis His kinase 2 (AHK2), AHK3 and cytokinin response 1 (CRE1)/AHK4, are transmembrane proteins that autophosphorylate upon CK binding and transfer the phosphoryl group to Arabidopsis

His-phosphotransfer proteins (AHP). Eventually, AHP proteins translocate to the nucleus and the signal is transferred to the Arabidopsis response regulators (ARRs) transcription factors. There are four types of ARR proteins based on their protein similarity (To et al., 2007). Type B ARRs positively regulate the expression of $\mathrm{CK}$ responsive genes, including the type $\mathrm{A}$ ARRs that repress CK signaling. Additionally, the type B ARRs promote the expression of the cytokinin response factor (CRF) family of transcription factors (Rashotte et al., 2006). The CRF proteins accumulate in the nucleus depending on the activity of AHP proteins to regulate the expression of CK-responsive genes (Rashotte et al., 2006). The type C ARRs have phosphatase activity and are thought to regulate CK signaling negatively by removing the phosphoryl group from type B and type A ARRs (Kiba et al., 2004). The fourth group corresponds to the Arabidopsis pseudoresponse regulators that has been shown to participate in the regulation of the circadian rhythm (To et al., 2007).

(Continued)

\section{BOX 2 | Continued \\ - Brassinosteroids}

The steroid hormones BRs are perceived in the plasma membrane by a group of leucine-rich repeat receptor-like kinase (LRR-RKL) receptors

(brassinosteroid insensitive 1, BRI, and brassinosteroid receptor-like 1 BRL1 and BRL3 in Arabidopsis) that, upon BR binding, elicit a signal transduction cascade that inhibits BR-insensitive 2 (BIN2) (Zhu et al., 2013). In the absence of BR, BIN2 phosphorylates the transcription factors EMS suppressor 1 (BES1) and brassinazole-resistant 1 (BZR1), blocking their ability to bind their DNA targets (Belkhadir et al., 2014). Upon BR binding by the receptors, a signaling cascade is induced that ultimately results in dephosphorylation and increased nuclear localization of BES1/BZR1, which can in turn regulate the expression of BR-responsive genes (Belkhadir et al., 2014).

\section{- Abscisic Acid}

The ABA signaling pathway is elicited when the hormone binds to the PYR/PYL/RCAR receptor proteins that release SnRK2s kinases from PP2Cs inhibition, thereby activating the ABF/AREB transcription factors to regulate the expression of ABA-responsive genes (Santner et al., 2009).

Protein degradation processes regulate the progression of the cell cycle (Gutierrez, 2009), and they have been found important for the control of QC cell divisions (Ueda et al., 2004; Vanstraelen et al., 2009). For example, HALTED ROOT (HLR) encodes a subunit of the ubiquitin $26 \mathrm{~S}$ proteasome, and the hlr mutant displays dividing QC cells and a loss of the expression of characteristic markers of these cells (Ueda et al., 2004). It has been shown that the $h l r$ mutant is defective in auxin signaling, as the degradation of IAA17 is compromised (Ueda et al., 2004). IAA17 is a member of the family of AUX/IAA repressors (Box 2), which interact with the ARF transcription factors and impede them to regulate the expression of auxin-responsive genes (Ulmasov et al., 1997, 1999; Okushima et al., 2005; Guilfoyle and Hagen, 2007). Notably, IAA17 and WOX5 act in the same regulatory pathway in the QC cells (Ding and Friml, 2010; Tian et al., 2014). An IAA17 gain-of-function mutant has altered auxin levels in the QC cells, multiple layers of the distal ICs, and an expanded WOX5 expression domain (Ding and Friml, 2010; Tian et al., 2014). This phenotype clearly shows that if the degradation of IAA17 is compromised, as observed in the hlr mutant, there will be defects in the organization of the QC cells and the SCN (Ueda et al., 2004). The defects of the IAA17 gain-of-function mutant concerning the restriction in the expression of WOX5 could be related to the regulation of MP and ARF10, as both interact with this particular AUX/IAA repressor (Vernoux et al., 2011; Piya et al., 2014) and both regulate WOX5, as it was mentioned in the previous section.

The CELL CYCLE SWITCH 52 A1 (CCS52A1) and CCS52A2 protein isoforms are components of the ANAPHASEPROMOTING COMPLEX/CYCLOSOME (APC/C) that targets several cell cycle proteins for degradation, important for cell cycle progression and mitosis (Vanstraelen et al., 2009). Interestingly, APC regulates mitotic arrest in the QC and also the onset of endocycle in the transition domain of the root meristem (Vanstraelen et al., 2009; Heyman et al., 2013; Takahashi and Umeda, 2014). In the ccs52a2 loss-of-function mutant, the QC cells divide more frequently than in wild-type plants, 
and the meristem is eventually exhausted (Vanstraelen et al., 2009; Heyman et al., 2013). One of the regulatory targets of CCS52A2 is ETHYLENE RESPONSE FACTOR 115 (ERF115), whose expression is observed prior to the division of QC cells (Heyman et al., 2013). ERF115 activates the expression of phytosulfokine5 (PSK5), a peptide hormone that induces QC cell divisions (Heyman et al., 2013). Overexpression of ERF115 results in a marked increase in the frequency of QC cell divisions in the root SCN, indicating that it is a positive regulator of QC mitotic activity. Although ERF115 has been annotated as an ethylene response factor, its expression is actually not regulated by ethylene. Instead it is induced by ROS signaling (Kong et al., 2018) and brassinolide (BL) treatment (Heyman et al., 2013). Notably, QC cell divisions still take place in erf115 mutants treated with BL (Heyman et al., 2013), indicating that BR also promotes cell divisions independently of ERF115 (Vilarrasa-Blasi et al., 2014).

Recently, it was found that ULTRAPETALA1 (ULT1), described as a trithorax ( $\operatorname{Trx} G)$ component, is also required for QC cell divisions, evidencing the participation of the epigenetic factors in this process (Ornelas-Ayala et al., 2020).

\section{REDOX REGULATION OF QC CELL DIVISION}

Redox regulation plays a critical role in the organization of the RAM in Arabidopsis (Tsukagoshi et al., 2010), but its role in the QC is not so clear. In this section, we include research studies from maize regarding the function of redox regulation in the QC cells, in order to provide insights of its role in Arabidopsis.

In maize roots, the boundary between the QC and the proliferating cells of the meristem is marked by a drastic change in the redox cellular state (Kerk and Feldman, 1995; Jiang et al., 2003). The position of the QC in the root apex is characterized by an oxidizing environment with high levels of dehydroascorbic acid (DHA) and glutathione disulfide, whereas a reduced state is detected in the neighboring cells in the RAM with high levels of ascorbic acid (AA) and glutathione (GSH) (Kerk and Feldman, 1995; Jiang et al., 2003). The redox profiles of the quiescent SCs and the proliferative meristematic cells could be important in the definition of these zones of contrasting mitotic activity. This notion is supported by experiments in which the QC cells start dividing in maize roots treated with AA, whereas cells become arrested in the G1 phase of the cell cycle when roots are treated with an inhibitor of AA biosynthesis (Kerk and Feldman, 1995, and references therein), indicating the importance of the redox status in the regulation of QC cell divisions.

Reduced compounds such as AA and GSH, which are enriched in meristematic cells of maize, are necessary for the progression of many generic cellular processes including the transition from G1 to $S$ phase of the cell cycle, metabolic reactions, and protein synthesis (Kerk and Feldman, 1995; Vernoux et al., 2000; Jiang and Feldman, 2005; De Tullio et al., 2010). The molecular mechanism behind these effects may involve these molecular species acting as second messengers in signaling pathways (Apel and Heribert, 2004) and in the regulation of protein activity and conformation. In Arabidopsis, this could be mediated through the oxidation/reduction of cysteine residues in enzymes and transcription factors (De Tullio et al., 2010), which potentially could modulate the information processing capabilities of the cells. AA has been suggested to affect ethylene biosynthesis (Arrigoni and Tullio, 2000). As ethylene induces QC cell division (Ortega-Martínez et al., 2007), this potentially represents another mechanism by which the redox status of the cell regulates QC cell division.

In Arabidopsis, several reports indicate the importance of the redox status of the QC cells in the maintenance of their low mitotic rate. For instance, the app1 mutant, a mutant in a mitochondrial ATPase, has altered levels of reactive oxygen species (ROS) in the cells of the RAM and displays an increase in QC cell division (Yu et al., 2016; Kong et al., 2018). Interestingly, this phenotype is accompanied by a reduction in the expression of the transcription factors SCR and SHR (Yu et al., 2016). Salicylic acid (SA) is a hormone that plays an important role in plant defense, and it induces QC cell divisions in a dose-dependent manner (Wang et al., 2020). The SA-induced cell divisions are mediated by an increase in ROS levels the RAM and a downregulation of PLT1, PLT2, and WOX5 in the QC cells (Wang et al., 2020). It was also previously shown that increased ROS levels cause a downregulation of PLT genes, a higher expression of ERF115, among other factors (Kong et al., 2018). Altogether, these studies in Arabidopsis indicate a key role of redox regulation in QC cell divisions and show the existence of interesting links between QC cell identity and its proliferative state.

It is remarkable that in neural SCs, ROS production in mitochondria has also been shown to regulate SC fate by regulating the expression of key developmental genes (Khacho et al., 2016), suggesting that this could be a generic mechanism for the control SC activity as a response of the internal redox state of the cells.

\section{HORMONAL REGULATION OF QC MITOTIC ACTIVITY}

Auxin and $\mathrm{CK}$, as well as $\mathrm{BR}$ and $\mathrm{ABA}$, have antagonistic roles in different developmental contexts, including the division of the QC cells in the root SCN. In this section, we review the regulatory crosstalk between these two pairs of antagonistic hormones. All interactions were included in a network that illustrates the complexity underlying QC cell division (Figure 2E). Other plant hormones such as gibberellins are not included in this review because it has been demonstrated to regulate root growth independently of the activity of the SCN (Achard et al., 2009; Ubeda-Tomás et al., 2009; González-García et al., 2011).

\section{Auxin and CK Antagonism in the Regulation of the QC Cell Divisions}

In the root $\mathrm{SCN}$, WOX5 promotes auxin accumulation in the QC by inducing the expression of the auxin biosynthetic enzymes YUCCA1 (Tian et al., 2014), tryptophan aminotransferase of arabidopsis1 (TAA1; Savina et al., 2020), and by repressing the expression of auxin conjugation genes (Gonzali et al., 
2005). As WOX5 expression is induced by auxin in the QC (Sarkar et al., 2007), this establishes an auxin-WOX5-positive feedback loop in these cells. Moreover, SCR controls auxin levels in the QC cells by indirectly repressing the expression of ASB1 (ANTHRANILATE SYNTHASE BETA SUBUNIT 1), an enzyme involved in auxin biosynthesis (Moubayidin et al., 2013). Consequently, in the scr-1 mutant, the auxin content is dramatically increased, and the SCN is disorganized (Moubayidin et al., 2013). This suggests that auxin levels have to be actively modulated in the QC cells, to maintain appropriate levels for the long-term organization of the root SCN.

In the QC cells, auxin indirectly promotes low division rates through the positive regulation of WOX5, maintaining low levels of CYCD3;3 in these cells (Figure 2D). A study from maize suggests another mechanism by which auxin may impact on QC cell divisions. In maize roots, auxin promotes the expression and the activity of the enzyme ascorbate oxidase $(A A O)$, which oxidizes AA to DHA (Kerk and Feldman, 1995). AAO expression is high in the QC, moderate in the meristem, and absent in the mature root (Kerk and Feldman, 1995), correlating with the auxin concentration gradient along the RAM. As mentioned in the previous section, in maize, the QC cells have a redox status different to that of the meristem cells. The spatial distribution of auxin and $A A O$ along the RAM suggests that the redox status of the cells may be established, at least in part, by auxin. In support of this idea, maize roots treated with $1-N$-naphtylphthalamic acid (NPA), an inhibitor of auxin efflux transport, display changes in auxin distribution, and the QC becomes less oxidized (Jiang et al., 2003). This change in the redox state of the QC preceded the incorporation of the nucleotide analog, BrdU, strongly suggesting that this change in the redox status of the QC cells underlies the increase in their proliferation rate (Jiang et al., 2003). Based on these results, it was proposed that high levels of auxin in the QC cells regulate the redox status of the cells and maintain low proliferation rates of the QC cells (Jiang et al., 2003). It remains to be determined if this redox regulation also occurs in Arabidopsis. Experiments in Arabidopsis indicate that SA-induced QC cell divisions are accompanied by an increase in ROS levels and a decrease in auxin signaling in the QC cells (Wang et al., 2020), thus suggesting the existence of a mechanism similar to the one described in maize roots.

Cytokinins have an antagonistic function to auxin in different developmental processes. For instance, the crosstalk between these hormones regulates the balance between proliferation and differentiation in the RAM (Moubayidin et al., 2009; Su et al., 2011; Aichinger et al., 2012; Rodriguez-Villalon and Hardtke, 2014). In the QC, these hormones also have antagonistic role as $\mathrm{CK}$ induces cell division. Plants with increased $\mathrm{CK}$ signaling display ectopic division of the QC cells (Zhang et al., 2011, 2013). For example, the arr3,4,5,6,7,8,9,15 loss-of-function multiple mutant in numerous type A ARRs results in CK hypersensitivity and a higher rate of cell division in the QC compared with wildtype plants (Zhang et al., 2011). This phenotype is accompanied by the differentiation of the distal ICs and mild alterations in the auxin response of the QC, indicating that type A ARRs are necessary for maintaining appropriate activity of the QC (Zhang et al., 2011).
Wild-type roots treated with exogenous CK and CK oxidase mutants ( $c k x 3$ and $c k \times 5)$ with elevated endogenous levels of CK also show an increase in QC cell division (Zhang et al., 2013). Expression analyses showed that WOX5 and SCR, as well as the auxin influx transporters $A U X 1$ and $L A X 2$, are downregulated in the QC of these mutants (Zhang et al., 2013). Interestingly, ARR1 (type B ARR) directly binds to the promoter of $L A X 2$, which is expressed in the provascular tissues and the QC cells (Péret et al., 2012), and the QC cells divide in the lax2 mutant (Zhang et al., 2013). Furthermore, in roots treated with exogenous CK, LAX2 expression is repressed, resulting in dampening auxin accumulation in the QC cells. Hence, the induction of QC cell division by $\mathrm{CK}$ could be an indirect result of lowering auxin levels in the QC. This evidence agrees with a notion where high auxin concentration in the QC promotes a state of no cell divisions. It is interesting that $\mathrm{CK}$ levels in the QC cells are rather low, whereas these increase in the neighboring cells (Zhang et al., 2013; Zürcher et al., 2013; Antoniadi et al., 2015), suggesting that a tight spatial regulation of $\mathrm{CK}$ metabolism and signaling is important to maintain the QC cells.

\section{Effects of BRs and ABA in the Regulation of QC Cell Divisions}

Treating wild-type seedlings with exogenous L-brassinolide (BL) induces the division of the QC cells and the differentiation of distal ICs in a dose-dependent manner (González-García et al., 2011; Fàbregas et al., 2013). Accordingly, the gain-of-function bzr1-1d has actively dividing QC cells even if BR biosynthesis is blocked (Chaiwanon and Wang, 2015). Two of the three known $\mathrm{BR}$ receptors, namely, BRL1 and BRL3, are detected mainly in the root SCN (Fàbregas et al., 2013), and their loss-of-function mutants show a reduction in the division rate of the QC cells in comparison with wild-type seedlings (Fàbregas et al., 2013). The protein of the third $\mathrm{BR}$ receptor, $\mathrm{BRI} 1$, is detected in the root meristem but not in the QC (van Esse et al., 2011; Fàbregas et al., 2013). Interestingly, despite this apparent absence of BRI1 in the QC cells, it is necessary for BR-induced QC cell divisions, as in the bri1-116 mutant the divisions were completely abolished in roots treated with BL (Vilarrasa-Blasi et al., 2014).

The nuclear accumulation of BES1 and BZR1 can be used as a marker of the activity of the BR signaling. In the SCN, these proteins accumulate mostly in the cytoplasm indicating that the BR signaling pathway is not active in these cells (Chaiwanon and Wang, 2015). As the QC cells of young Arabidopsis roots are mitotically quiescent, endogenous mechanisms to maintain BR signaling low in these cells may exist. Based on current evidence, this might be mediated by a low accumulation of BRI1 protein in the QC cells (van Esse et al., 2011; Fàbregas et al., 2013) and by the auxin-dependent increased local BR catabolism in the root SCN area (Chaiwanon and Wang, 2015).

Brassinosteroids signaling negatively affects the expression of a significant number of QC-enriched genes, suggesting that loss of QC identity is linked to an increase in its proliferation (Chaiwanon and Wang, 2015). The MYB transcription factor BRASSINOSTEROIDS AT VASCULAR AND ORGANIZING 
CENTER (BRAVO) was identified as the only BR-regulated gene that is a direct target of BES1 and BZR1 in the proximal ICs and the QC cells (Vilarrasa-Blasi et al., 2014). BRAVO expression is reduced upon $\mathrm{BL}$ treatment in a time- and dose-dependent manner, and this reduction occurs before the BL-induced QC cell divisions (Vilarrasa-Blasi et al., 2014). The bravo loss-offunction mutant has increased mitotic activity of the QC cells and a dramatic reduction in the expression of WOX5 and other QC markers (Vilarrasa-Blasi et al., 2014). In the roots of ectopic expression inducible lines of $B R A V O$, several cell cycle genes are downregulated including $C Y C D 2 ; 2$ and $C Y C D 3 ; 3$, providing clues of the mechanism by which BRAVO may impact on the cell cycle progression to repress QC divisions. Intriguingly, loss-of-function wox5-1 mutants show resistance to $\mathrm{BR}$ with respect to QC cell proliferation (González-García et al., 2011), indicating that WOX5 is a crucial regulator for the BR-induced QC divisions. This evidence supports a conceptual model where QC cell identity is intimately linked with cell division. In the case of $\mathrm{BR}$, the activation of QC cell divisions may be mediated, in part, by relieving the WOX5-dependent inhibition of $C Y C D 3 ; 3$ (Figure 2D). As both BRAVO and WOX5 regulate negatively the expression of CYCD3;3 (Forzani et al., 2014; Vilarrasa-Blasi et al., 2014), it is tempting to speculate that BRAVO acts through WOX5 in the regulation of QC mitotic activity. Additionally, as BRAVO affects the expression of other cell cycle regulators, it is likely that it also regulates QC cellular quiescence through a parallel pathway (Vilarrasa-Blasi et al., 2014).

On the other hand, ABA has been reported to maintain the quiescent state of the QC cells. Indeed, the low division rate of the $\mathrm{QC}$ cells is compromised in $\mathrm{ABA}$-deficient and ABA-insensitive mutants, and in wild-type plants treated with fluridone, an inhibitor of ABA biosynthesis (Zhang et al., 2010). Roots of these plants display increased differentiation of distal ICs, and in some cases, the QC cells had starch granules (Zhang et al., 2010), suggesting that the function and identity of the QC are severely compromised. On the contrary, exogenous ABA treatment induced the quiescence of the QC cells, reduced distal IC differentiation, and increased the expression of root SCN regulators, as PLT2, MP, and WOX5 (Zhang et al., 2010). WOX5 mediates the effect of ABA in preventing distal IC differentiation, as treatment of wox5-1 mutants with either ABA or fluridone no longer altered the differentiation pattern of distal IC (Zhang et al., 2010). Moreover, it has been reported that overexpression of WOX5 (35S:WOX5) potentiates ABA effects related to the additional distal ICs files (Sarkar et al., 2007; Zhang et al., 2010). Surprisingly, distal ICs became differentiated when 35S:WOX5 plants were treated with fluridone, strongly suggesting that the effect of WOX5 over distal ICs depends on ABA availability (Zhang et al., 2010). Altogether, the mentioned evidence indicates that $\mathrm{ABA}$ promotes the quiescence of the QC cells, in part by promoting the expression of WOX5 among other transcription factors, and there might exist a mutual interdependency between ABA and WOX5 to regulate the differentiation of distal ICs.

In summary, the antagonistic effects of BR and ABA on $\mathrm{QC}$ cell division are mediated in part by the regulation of QC cell factors, including WOX5. Interestingly, ABA treatment causes a slight increase of BRAVO expression (Vilarrasa-Blasi et al., 2014), suggesting that it could be a mediator of $\mathrm{BR}$ and $\mathrm{ABA}$ responses in the QC cells, although it remains to be determined if this is indeed the case.

\section{AN INTEGRATIVE REGULATORY MODULE FOR QC CELL IDENTITY AND CELL DIVISIONS}

The regulatory interactions related to the division of the QC cells described in the previous sections were integrated in a regulatory network that might constitute a developmental module of SC regulation (Figure 2E). Through this conceptual framework, it is possible to get insight into how each hormone is affecting the activity of the other elements of the network, and then understand how the system overall is responding to hormonal alterations. For instance, it can be noticed that WOX5 is a recurrent target in the hormonal regulation of QC cell division, making it a central component of the proposed regulatory module (Figure 2E). This convergent regulation of a QC-specific transcription factor suggests that the regulation of QC cell division by hormonal signaling pathways is intimately linked with QC cell identity (Figure 2). In this regard, it is remarkable that WOX5 directly represses CYCD3;3 (Forzani et al., 2014) because this establishes a direct link between cell fate regulation in the $\mathrm{QC}$ and mitotic quiescence. However, the low proliferation state of the QC cells might be maintained by other means, for example, by the activity of the proteasome (Ueda et al., 2004; Vanstraelen et al., 2009), through the direct regulation of various cell cycle components (Vilarrasa-Blasi et al., 2014), or, as suggested by studies from maize, by the regulation of the redox status of the cells (Kerk and Feldman, 1995; Jiang et al., 2003).

The notion that hormones are channeled toward a common regulatory module to adjust QC cell divisions is supported by reported antagonistic effects on the regulation of QC genes and of QC cell division. For example, auxin and BR have antagonistic effects in the regulation of QC quiescence, and most of the genes that are repressed by $\mathrm{BR}$ in the QC are induced by auxin (Chaiwanon and Wang, 2015). BRAVO and all PLTs are part of the genes regulated differentially by both auxin and BR (Chaiwanon and Wang, 2015), thus establishing a mechanism by which both hormones impact on the cell fate of the QC cells (Figures 2D,E). Auxin also promotes the expression of BR catabolic enzymes in order to maintain BR low levels in the root meristem cells and establishing auxin and BR domains with no overlapping responses (Chaiwanon and Wang, 2015). Thus, there are many ways in which this hormonal crosstalk takes place, and its study can be aided through a network approach.

In the case of auxin and CK, this pair of hormones has antagonistic roles in the regulation of cell division in both the RAM and in the QC cells. Intriguingly, auxin promotes cell proliferation in the meristem and mitotic quiescence in the QC (Kerk and Feldman, 1995; Ishida et al., 2010; Chaiwanon and Wang, 2015), whereas CK promotes the opposite (Dello ioio et al., 2008; Zhang et al., 2013). This indicates that there is a general antagonism between auxin and CK that is independent of the tissue context (Table $\mathbf{1}$ ). The regulatory crosstalk between auxin 
and $\mathrm{CK}$ is not necessarily conserved in the root meristem and the QC (reviewed in Garay-Arroyo et al., 2012; Table 1). For example, CK induces the expression of the Aux/IAA repressor SHY2 to regulate meristem size, and this is a key point in the regulatory crosstalk between auxin and CK (Dello ioio et al., 2008), but SHY2 is not involved in the regulation of CKinduced QC cell division (Zhang et al., 2013). Therefore, how the hormonal regulatory modules act in the meristematic cells and in the QC, and how they are coupled remain to be uncovered. The opposite effects of these hormones in the meristem and the QC could be due to quantitative variations in its levels and the specific gene activity profile in each context (Fridman et al., 2014; Vragović et al., 2015). Thus, considering the gene regulatory network that underlies the acquisition of different fates in the RAM could be very instrumental to understand the opposite effects of these hormones in the different zones of the root apex (García-Gómez et al., 2017).

It is interesting that there are mutants with RAM defects, which display QC cell divisions despite maintaining WOX5 expression, indicating that, although it is a central component in the hormonal regulation of QC cell division, it is not enough to maintain a quiescence cell state. Examples of this are the ccs52a2 loss-of-function mutant (Vanstraelen et al., 2009), BR gain-of-function signaling mutants (González-García et al., 2011), a mutant with SA overaccumulation (Wang et al., 2020), a down-regulation of $r b r$ in the QC cells (CruzRamírez et al., 2013), and mutants affecting folate metabolism (Reyes-Hernández et al., 2014) and threonine synthesis (ReyesHernández et al., 2019). As reviewed here, other important regulators of QC divisions include the redox status of the cells (Kerk and Feldman, 1995; Jiang et al., 2003) and BRAVO, which controls the expression of several cell cycle genes (Vilarrasa-Blasi et al., 2014). This could constitute parallel ways in which the division of the QC cells can be modulated independently of WOX5. As we learn more about the effects of hormones on the activity of the cell fate regulators of the root SCN, these could be integrated into the network to assess their effect on the other key elements of QC cell regulation (Figure 2E).

Regarding jasmonic acid (JA), a report showed that it induces QC cell proliferation, and it has been suggested to be through the control of the transition from the G2 to $M$ phase of the cell cycle (Chen et al., 2011). Additionally, JA signaling inhibits the expression of the auxin-responsive genes PLT1 and PLT2 (Chen et al., 2011), and recent reports show that it promotes QC cell division through the RBR-SCR regulatory circuit and ERF115 (Zhou et al., 2019), thus connecting JA signaling with the regulatory module controlling cell fate and division in the QC. Moreover, auxin induces the expression of ERF115 during regeneration as QC cell divisions take place (Zhou et al., 2019), indicating a multistability of auxin signaling in the regulation of QC cell divisions. Ethylene also promotes the proliferation of the QC cells, but the molecular mechanism is currently unknown (Ortega-Martínez et al., 2007). It has been reported that this ethylene effect on QC cell division is achieved independently of auxin, BR, CK, and JA (Chen et al., 2011; Heyman et al., 2013; Zhang et al., 2013). Curiously, in maize roots, NPA-induced QC cell divisions are reverted by cotreatment with an ethylene precursor ACC, indicating a regulatory interaction between these hormones in the regulation of the QC (Ponce et al., 2005). In this study, it is suggested that this might be a non-cellautonomous effect mediated by a deregulation of auxin transport (Ponce et al., 2005).

Finally, the hormonal regulatory interactions that underlie QC cellular quiescence are non-linear and occur in a multicellular context, so an integrative approach of regulatory networks could aid in understanding these interactions (Azpeitia and AlvarezBuylla, 2012; García-Gómez et al., 2020).

TABLE 1 | Hormonal regulatory effects in the QC and root meristem cells.

\begin{tabular}{|c|c|c|c|c|c|c|}
\hline Hormone & $\begin{array}{l}\text { Link to primary } \\
\text { metabolism }\end{array}$ & Effect in the QC & $\begin{array}{l}\text { Effect in the } \\
\text { meristem }\end{array}$ & $\begin{array}{l}\text { Regulation of SCN } \\
\text { transcription factors }\end{array}$ & $\begin{array}{l}\text { Other regulated } \\
\text { genes at the } \\
\text { root tip }\end{array}$ & References \\
\hline Brassinosteroids & - & Proliferation & $\begin{array}{l}\text { Proliferation and } \\
\text { differentiation }\end{array}$ & $\begin{array}{l}\text { WOX5, PLT1, PLT2, } \\
\text { BBM, and AGL42. }\end{array}$ & BRAVO and KRP2 & $\begin{array}{l}\text { González-García et al., } \\
\text { 2011; Vilarrasa-Blasi } \\
\text { et al., 2014; Vragović } \\
\text { et al., 2015; Chaiwanon } \\
\text { and Wang, } 2015\end{array}$ \\
\hline Abscisic acid & - & Quiescence & $\begin{array}{l}\text { Proliferation and } \\
\text { differentiation }\end{array}$ & WOX5, MP, and PLT2 & & Zhang et al., 2010 \\
\hline Auxin & Tryptophane & Quiescence & Proliferation & $\begin{array}{l}\text { WOX5, PLT1, PLT2, } \\
\text { BBM, and BRAVO }\end{array}$ & $\begin{array}{l}\text { AAO (in maize } \\
\text { roots) and BR } \\
\text { catabolic enzymes }\end{array}$ & $\begin{array}{l}\text { Kerk and Feldman, } \\
\text { 1995; Aida et al., 2004; } \\
\text { Galinha et al., 2007; } \\
\text { Sarkar et al., 2007; } \\
\text { Chaiwanon and Wang, } \\
2015\end{array}$ \\
\hline Cytokinin & Adenine & Proliferation & Differentiation & WOX5 and SCR & $\begin{array}{l}\text { LAX2, SHY2 and } \\
\text { CCS52A1 }\end{array}$ & $\begin{array}{l}\text { Dello ioio et al., 2008; } \\
\text { Takahashi and Umeda, } \\
\text { 2014; Zhang et al., } \\
2013\end{array}$ \\
\hline Jasmonic acid & Isoleucine & Proliferation & Differentiation & PLT1 and PLT2 & & Chen et al., 2011 \\
\hline Ethylene & Methionine & Proliferation & - & - & TAA1 & Stepanova et al., 2008 \\
\hline
\end{tabular}




\section{PERSPECTIVES}

The interconnection of hormonal signaling pathways, regulators of cell division, and the cell identity of the QC cells is an exciting matter of research that could reveal systemic mechanisms by which SC activity in plants is dynamically modulated to adapt to changing environmental and physiological conditions. Although this is of interest to the field of plant development, recent reports in animal SCNs are finding features that are also present in plant SCNs (Li and Clevers, 2010), and thus, what we learn about the QC regulation could potentially uncover generic regulatory mechanisms of SCs. Some of the most remarkable similarities between plant and animal SCNs are the coexistence of two adjoining populations of SCs with different proliferation rates (Barlow, 1978, 1997; Jiang and Feldman, 2005; Li and Clevers, 2010) and also the dual role of SCs that can act as organizers and also maintain their progeny undifferentiated (van den Berg et al., 1997; Pardo-Saganta et al., 2015). The functional meaning of SCs acting both as the organizer of the SCN and as SCs, as is the case for the QC in the root $\mathrm{SCN}$, is possibly related to the self-organizing properties of the SCNs and the dynamic regulation of its size at the organ level. Furthermore, the existence of a population of SCs with different division rates results in the preservation of this population of cells for longer times, protecting them against deleterious mutations that otherwise might spread to the whole tissue (Clowes, 1956; Scadden, 2006). The root SCN is a well-described niche at the anatomical level, and we have a good understanding of the regulatory networks that underlie the acquisition of cell identity and hormonal

\section{REFERENCES}

Aceves-García, P., Álvarez-Buylla, E. R., Garay-Arroyo, A., García-Ponce, B., Muñoz, R., and de la Paz Sánchez, M. (2016). Root architecture diversity and meristem dynamics in different populations of Arabidopsis thaliana. Front. Plant Sci. 7:858. doi: 10.3389/fpls.2016.00858

Achard, P., Gusti, A., Cheminant, S., Alioua, M., Dhondt, S., Coppens, F., et al. (2009). Gibberellin signaling controls cell proliferation rate in Arabidopsis. Curr. Biol. 19, 1188-1193. doi: 10.1016/j.cub.2009.05.059

Aichinger, E., Kornet, N., Friedrich, T., and Laux, T. (2012). Plant stem cell niches. Annu. Rev. Plant Biol. 63, 615-636. doi: 10.1146/annurev-arplant-042811105555

Aida, M., Beis, D., Heidstra, R., Willemsen, V., Blilou, I., Galinha, C., et al. (2004). The PLETHORA genes mediate patterning of the Arabidopsis root stem cell niche. Cell 119, 109-120. doi: 10.1016/j.cell.2004.09.018

Alvarado, A. S., and Yamanaka, S. (2014). Rethinking differentiation: stem cells, regeneration, and plasticity. Cell 157, 110-119. doi: 10.1016/j.cell.2014.02.041

Antoniadi, I., Plačková, L., Simonovik, B., Doležal, K., Turnbull, C., Ljung, K., et al. (2015). Cell-type-specific cytokinin distribution within the Arabidopsis primary root apex. Plant Cell 27, 1955-1967. doi: 10.1105/tpc.15.00176

Apel, K., and Heribert, H. (2004). Reactive oxygen species: metabolism, oxidative stress, and signal transduction. Annu. Rev. Plant Biol. 55, 373-399. doi: 10.1146/ annurev.arplant.55.031903.141701

Arrigoni, O., and De Tullio, M. C. (2000). The role of ascorbic acid in cell metabolism: between gene-directed functions and unpredictable chemical reactions. J. Plant Physiol. 157, 481-488. doi: 10.1016/S0176-1617(00)80102-9

Azpeitia, E., and Alvarez-Buylla, E. R. (2012). A complex systems approach to Arabidopsis root stem-cell niche developmental mechanisms: from molecules, to networks, to morphogenesis. Plant Mol. Biol. 80, 351-363. doi: 10.1007/ s11103-012-9954-6 profiles. Thus, the root $\mathrm{SCN}$ is a model system to describe the constraints of hormonal regulation of SCs activity that will then be instrumental to understand how the same may be occurring in other systems. The conceptual framework we presented in this review constitutes an important step toward this goal.

\section{AUTHOR CONTRIBUTIONS}

All authors listed have made a substantial, direct and intellectual contribution to the work, and approved it for publication.

\section{FUNDING}

This study was financed with the following grants: Programa de Apoyo a Proyectos de Investigación e Innovación Tecnológica Universidad Nacional Autónoma de México (UNAMDGAPA-PAPIIT http://dgapa.unam.mx/index.php/impulsoa-la-investigacion/papiit): IN200920, IN203220, IN206220, IN211721, and Consejo Nacional de Ciencia y Tecnología (CONACyT): 102959 and 102987. The funders had no role in study design, data collection and analysis, decision to publish, or preparation of the manuscript.

\section{ACKNOWLEDGMENTS}

We acknowledge the help from Diana Belén Sánchez-Rodríguez with various logistical tasks.

Barlow, P. W. (1978). "The concept of the stem cell in the context of plant growth and development," in Stem Cells and Tissue Homeostasis, (Cambridge: Cambridge University. Press), 87-113.

Barlow, P. W. (1997). "Stem cells and founder zones in plants, particularly their roots," in Stem Cells, ed C. S. Poten (London: Academic), 29-57. doi: 10.1016/ B978-012563455-7/50003-9

Baum, S. F., Dubrovsky, J. G., and Rost, T. L. (2002). Apical organization and maturation of the cortex and vascular cylinder inArabidopsis thaliana (Brassicaceae) roots. Am. J. Bot. 89, 908-920. doi: 10.3732/ajb.89.6.908

Belkhadir, Y., Yang, L., Hetzel, J., Dangl, J. L., and Chory, J. (2014). The growthdefense pivot: crisis management in plants mediated by LRR-RK surface receptors. Trends Biochem. Sci. 39, 447-456. doi: 10.1016/j.tibs.2014.06.006

Benfey, P. N., Linstead, P. J., Roberts, K., Schiefelbein, J. W., Hauser, M. T., and Aeschbacher, R. A. (1993). Root development in Arabidopsis: four mutants with dramatically altered root morphogenesis. Development 119, 57-70.

Blilou, I., Xu, J., Wildwater, M., Willemsen, V., Paponov, I., Friml, J., et al. (2005). The PIN auxin efflux facilitator network controls growth and patterning in Arabidopsis roots. Nature 433, 39-44. doi: 10.1038/nature03184

Brunoud, G., Wells, D. M., Oliva, M., Larrieu, A., Mirabet, V., Burrow, A. H., et al. (2012). A novel sensor to map auxin response and distribution at high spatio-temporal resolution. Nature 482, 103-106. doi: 10.1038/nature10791

Calderón Villalobos, L. I. A. C., Lee, S., De Oliveira, C., Ivetac, A., Brandt, W., Armitage, L., et al. (2012). A combinatorial TIR1/AFB-Aux/IAA co-receptor system for differential sensing of auxin. Nat. Chem. Biol. 8, 477-485. doi: 10. 1038/nchembio.926

Chaiwanon, J., and Wang, Z. Y. (2015). Spatiotemporal brassinosteroid signaling and antagonism with auxin pattern stem cell dynamics in Arabidopsis roots. Curr. Biol. 25, 1031-1042. doi: 10.1016/j.cub.2015.02.046

Chen, Q., Sun, J., Zhai, Q., Zhou, W., Qi, L., Xu, L., et al. (2011). The basic helix-loop-helix transcription factor MYC2 directly represses PLETHORA 
expression during jasmonate-mediated modulation of the root stem cell niche in Arabidopsis. Plant Cell Online 23, 3335-3352. doi: 10.1105/tpc.111.089870

Clark, N. M., Fisher, A. P., Berckmans, B., Van den Broeck, L., Nelson, E. C., Nguyen, T. T., et al. (2020). Protein complex stoichiometry and expression dynamics of transcription factors modulate stem cell division. Proc. Natl. Acad. Sci. U.S.A. 117, 15332-15342. doi: 10.1073/pnas.2002166117

Clowes, F. A. L. (1956). Localization of nucleic acid synthesis in root meristems. J. Exp. Bot. 7, 307-312. doi: 10.1093/jxb/7.3.307

Cruz-Ramírez, A., Díaz-Triviño, S., Wachsman, G., Du, Y., Arteága-Vázquez, M., Zhang, H., et al. (2013). A SCARECROW-RETINOBLASTOMA protein network controls protective quiescence in the Arabidopsis root stem cell organizer. PLoS Biol. 11:e1001724. doi: 10.1371/journal.pbio.1001724

Cui, H., Levesque, M. P., Vernoux, T., Jung, J. W., Paquette, A. J., Gallagher, K. L., et al. (2007). An evolutionarily conserved mechanism delimiting SHR movement defines a single layer of endodermis in plants. Science 316, 421-425. doi: 10.1126/science.1139531

de Almeida Engler, J., De Veylder, L., De Groodt, R., Rombauts, S., Boudolf, V., De Meyer, B., et al. (2009). Systematic analysis of cell-cycle gene expression during Arabidopsis development. Plant J. 59, 645-660. doi: 10.1111/j.1365-313X.2009. 03893.x

De Tullio, M. C., Jiang, K., and Feldman, L. J. (2010). Redox regulation of root apical meristem organization: connecting root development to its environment. Plant Physiol. Biochem. 48, 328-336. doi: 10.1016/j.plaphy.2009.11.005

Dello ioio, R., Nakamura, K., Moubayidin, L., Perilli, S., Taniguchi, M., Morita, M. T., et al. (2008). A genetic framework for the control of cell division and differentiation in the root meristem. Science 322, 1380-1384. doi: 10.1126/ science. 1164147

Dharmasiri, N., Dharmasiri, S., and Estelle, M. (2005). The F-box protein TIR1 is an auxin receptor. Nature 435, 441-445. doi: 10.1038/nature03543

Di Laurenzio, L., Wysocka-Diller, J., Malamy, J. E., Pysh, L., Helariutta, Y., Freshour, G., et al. (1996). The SCARECROW gene regulates an asymmetric cell division that is essential for generating the radial organization of the Arabidopsis root. Cell 86, 423-433. doi: 10.1016/S0092-8674(00)80115-4

Ding, Z., and Friml, J. (2010). Auxin regulates distal stem cell differentiation in Arabidopsis roots. Proc. Natl. Acad. Sci. U.S.A. 107, 12046-12051. doi: 10.1073/ pnas. 1000672107

Dolan, L., Janmaat, K., Willemsen, V., Linstead, P., Poethig, S., Roberts, K., et al. (1993). Cellular organisation of the Arabidopsis thaliana root. Development 119, 71-84.

Fàbregas, N., Li, N., Boeren, S., Nash, T. E., Goshe, M. B., Clouse, S. D., et al. (2013). The BRASSINOSTEROID INSENSITIVE1-LIKE3 signalosome complex regulates Arabidopsis root development. Plant Cell 25, 3377-3388. doi: $10.1105 /$ tpc.113.114462

Forzani, C., Aichinger, E., Sornay, E., Willemsen, V., Laux, T., Dewitte, W., et al. (2014). WOX5 suppresses CYCLIN D activity to establish quiescence at the center of the root stem cell niche. Curr. Biol. 24, 1939-1944. doi: 10.1016/j.cub. 2014.07.019

Fridman, Y., Elkouby, L., Holland, N., Vragović, K., Elbaum, R., and SavaldiGoldstein, S. (2014). Root growth is modulated by differential hormonal sensitivity in neighboring cells. Genes Dev. 28, 912-920. doi: 10.1101/gad. 239335.114

Galinha, C., Hofhuis, H., Luijten, M., Willemsen, V., Blilou, I., Heidstra, R., et al. (2007). PLETHORA proteins as dose-dependent master regulators of Arabidopsis root development. Nature 449, 1053-1057. doi: 10.1038/ nature 06206

Garay-Arroyo, A., De La Paz Sánchez, M., García-Ponce, B., Azpeitia, E., and Álvarez-Buylla, E. R. (2012). Hormone symphony during root growth and development. Dev. Dyn. 241, 1867-1885. doi: 10.1002/dvdy.23878

García-Gómez, M. L., Azpeitia, E., and Álvarez-Buylla, E. R. (2017). A dynamic genetic-hormonal regulatory network model explains multiple cellular behaviors of the root apical meristem of Arabidopsis thaliana. PLoS Comput. Biol. 13:e1005488. doi: 10.1371/journal.pcbi.1005488

García-Gómez, M. L., Ornelas-Ayala, D., Garay-Arroyo, A., García-Ponce, B., de la Paz Sánchez, M., and Álvarez-Buylla, E. R. (2020). A system-level mechanistic explanation for asymmetric stem cell fates: Arabidopsis thaliana root niche as a study system. Sci. Rep. 10, 1-16.

González-García, M. P., Vilarrasa-Blasi, J., Zhiponova, M., Divol, F., Mora-García, S., Russinova, E., et al. (2011). Brassinosteroids control meristem size by promoting cell cycle progression in Arabidopsis roots. Development 138, 849859. doi: 10.1242/dev.057331

Gonzali, S., Novi, G., Loreti, E., Paolicchi, F., Poggi, A., Alpi, A., et al. (2005). A turanose-insensitive mutant suggests a role for WOX5 in auxin homeostasis in Arabidopsis thaliana. Plant J. 44, 633-645. doi: 10.1111/j.1365-313X.2005. 02555.x

Grieneisen, V. A., Xu, J., Marée, A. F., Hogeweg, P., and Scheres, B. (2007). Auxin transport is sufficient to generate a maximum and gradient guiding root growth. Nature 449, 1008-1013. doi: 10.1038/nature06215

Guilfoyle, T. J., and Hagen, G. (2007). Auxin response factors. Curr. Opin. Plant Biol. 10, 453-460. doi: 10.1016/j.pbi.2007.08.014

Gutierrez, C. (2009). The Arabidopsis cell division cycle. Arabidopsis Book 7:e0120. doi: $10.1199 /$ tab.0120

Heidstra, R., and Sabatini, S. (2014). Plant and animal stem cells: similar yet different. Nat. Rev. Mol. Cell Biol. 15, 301-312. doi: 10.1038/nrm3790

Helariutta, Y., Fukaki, H., Wysocka-Diller, J., Nakajima, K., Jung, J., Sena, G., et al. (2000). The SHORT-ROOT gene controls radial patterning of the Arabidopsis root through radial signaling. Cell 101, 555-567. doi: 10.1016/S0092-8674(00) 80865-X

Heyman, J., Cools, T., Vandenbussche, F., Heyndrickx, K. S., Van Leene, J., Vercauteren, I., et al. (2013). ERF115 controls root quiescent center cell division and stem cell replenishment. Science 342, 860-863. doi: 10.1126/ science. 1240667

Heyman, J., Kumpf, R. P., and De Veylder, L. (2014). A quiescent path to plant longevity. Trends Cell Biol. 24, 443-448. doi: 10.1016/j.tcb.2014.03.004

Ishida, T., Adachi, S., Yoshimura, M., Shimizu, K., Umeda, M., and Sugimoto, K. (2010). Auxin modulates the transition from the mitotic cycle to the endocycle in Arabidopsis. Development 137, 63-71. doi: 10.1242/dev.035840

Ivanov, V. B., and Dubrovsky, J. G. (2013). Longitudinal zonation pattern in plant roots: conflicts and solutions. Trends Plant Sci. 18, 237-243. doi: 10.1016/j. tplants.2012.10.002

Jiang, K., and Feldman, L. J. (2005). Regulation of root apical meristem development. Annu. Rev. Cell Dev. Biol. 21, 485-509. doi: 10.1146/annurev. cellbio.21.122303.114753

Jiang, K., Meng, Y. L., and Feldman, L. J. (2003). Quiescent center formation in maize roots is associated with an auxin-regulated oxidizing environment. Development 130, 1429-1438. doi: 10.1242/dev.00359

Kerk, N. M., and Feldman, N. J. (1995). A biochemical model for the initiation and maintenance of the quiescent center: implications for organization of root meristems. Development 121, 2825-2833.

Khacho, M., Clark, A., Svoboda, D. S., Azzi, J., MacLaurin, J. G., Meghaizel, C., et al. (2016). Mitochondrial dynamics impacts stem cell identity and fate decisions by regulating a nuclear transcriptional program. Cell Stem Cell 19, 232-247. doi: 10.1016/j.stem.2016.04.015

Kiba, T., Aoki, K., Sakakibara, H., and Mizuno, T. (2004). Arabidopsis response regulator, ARR22, ectopic expression of which results in phenotypes similar to the wol cytokinin-receptor mutant. Plant Cell Physiol. 45, 1063-1077. doi: $10.1093 / \mathrm{pcp} / \mathrm{pch} 128$

Kidner, C., Sundaresan, V., Roberts, K., and Dolan, L. (2000). Clonal analysis of the Arabidopsis root confirms that position, not lineage, determines cell fate. Planta 211, 191-199. doi: 10.1007/s004250000284

Kong, X., Tian, H., Yu, Q., Zhang, F., Wang, R., Gao, S., et al. (2018). PHB3 maintains root stem cell niche identity through ROS-responsive AP2/ERF transcription factors in Arabidopsis. Cell Rep. 22, 1350-1363. doi: 10.1016/j. celrep.2017.12.105

Levesque, M. P., Vernoux, T., Busch, W., Cui, H., Wang, J. Y., Blilou, I., et al. (2006). Whole-genome analysis of the SHORT-ROOT developmental pathway in Arabidopsis. PLoS Biol. 4:e143. doi: 10.1371/journal.pbio.0040143

Li, L., and Clevers, H. (2010). Coexistence of quiescent and active adult stem cells in mammals. Science 327, 542-545. doi: 10.1126/science.1180794

Liu, Y., Xu, M., Liang, N., Zheng, Y., Yu, Q., and Wu, S. (2017). Symplastic communication spatially directs local auxin biosynthesis to maintain root stem cell niche in Arabidopsis. Proc. Natl. Acad. Sci. U.S.A. 114, 4005-4010. doi: 10.1073/pnas.1616387114

Long, Y., Smet, W., Cruz-Ramírez, A., Castelijns, B., de Jonge, W., Mähönen, A. P., et al. (2015). Arabidopsis BIRD zinc finger proteins jointly stabilize tissue boundaries by confining the cell fate regulator SHORT-ROOT and contributing to fate specification. Plant Cell 27, 1185-1199. doi: 10.1105/tpc.114.132407 
Long, Y., Stahl, Y., Weidtkamp-Peters, S., Postma, M., Zhou, W., Goedhart, J., et al. (2017). In vivo FRET-FLIM reveals cell-type-specific protein interactions in Arabidopsis roots. Nature 548, 97-102. doi: 10.1038/nature23317

Mähönen, A. P., Ten Tusscher, K., Siligato, R., Smetana, O., Díaz-Triviño, S., Salojärvi, J., et al. (2014). PLETHORA gradient formation mechanism separates auxin responses. Nature 515, 125-129. doi: 10.1038/nature13663

Moreno-Risueno, M. A., Sozzani, R., Yard $\iota \mathrm{mcl}$, G. G., Petricka, J. J., Vernoux, T., Blilou, I., et al. (2015). Transcriptional control of tissue formation throughout root development. Science 350, 426-430. doi: 10.1126/science.aad1171

Moubayidin, L., Di Mambro, R., and Sabatini, S. (2009). Cytokinin-auxin crosstalk. Trends Plant Sci. 14, 557-562. doi: 10.1016/j.tplants.2009.06.010

Moubayidin, L., Di Mambro, R., Sozzani, R., Pacifici, E., Salvi, E., Terpstra, I., et al. (2013). Spatial coordination between stem cell activity and cell differentiation in the root meristem. Dev. Cell 26, 405-415. doi: 10.1016/j.devcel.2013.06.025

Nakajima, K., Sena, G., Nawy, T., and Benfey, P. N. (2001). Intercellular movement of the putative transcription factor SHR in root patterning. Nature 413, 307311. doi: 10.1038/35095061

Okushima, Y., Mitina, I., Quach, H. L., and Theologis, A. (2005). AUXIN RESPONSE FACTOR 2 (ARF2): a pleiotropic developmental regulator. Plant J. 43, 29-46. doi: 10.1111/j.1365-313X.2005.02426.x

Ornelas-Ayala, D., Vega-León, R., Petrone-Mendoza, E., Garay-Arroyo, A., García-Ponce, B., and Álvarez-Buylla, E. R. (2020). ULTRAPETALA1 maintains Arabidopsis root stem cell niche independently of ARABIDOPSIS TRITHORAX1. New Phytol. 225, 1261-1272. doi: 10.1111/nph.16213

Ortega-Martínez, O., Pernas, M., Carol, R. J., and Dolan, L. (2007). Ethylene modulates stem cell division in the Arabidopsis thaliana root. Science 317, 507-510. doi: 10.1126/science.1143409

Ortiz-Gutiérrez, E., García-Cruz, K., Azpeitia, E., Castillo, A., de la Paz Sanchez, M., and Álvarez-Buylla, E. R. (2015). A dynamic gene regulatory network model that recovers the cyclic behavior of Arabidopsis thaliana cell cycle. PLoS Comput. Biol. 11:e1004486. doi: 10.1371/journal.pcbi.1004486

Pardo-Saganta, A., Tata, P. R., Law, B. M., Saez, B., Chow, R. D. W., Prabhu, M., et al. (2015). Parent stem cells can serve as niches for their own daughter cells. Nature 523, 597-601. doi: 10.1038/nature14553

Péret, B., Swarup, K., Ferguson, A., Seth, M., Yang, Y., Dhondt, S., et al. (2012). AUX/LAX genes encode a family of auxin influx transporters that perform distinct functions during Arabidopsis development. Plant Cell 24, 2874-2885. doi: 10.1105/tpc.112.097766

Petersson, S. V., Johansson, A. I., Kowalczyk, M., Makoveychuk, A., Wang, J. Y., Moritz, T., et al. (2009). An auxin gradient and maximum in the Arabidopsis root apex shown by high-resolution cell-specific analysis of IAA distribution and synthesis. Plant Cell 21, 1659-1668. doi: 10.1105/tpc.109.066480

Pi, L., Aichinger, E., van der Graaff, E., Llavata-Peris, C. I., Weijers, D., Hennig, L., et al. (2015). Organizer-derived WOX5 signal maintains root columella stem cells through chromatin-mediated repression of CDF4 expression. Dev. Cell 33, 576-588. doi: 10.1016/j.devcel.2015.04.024

Piya, S., Shrestha, S. K., Binder, B., Stewart, C. N. Jr., and Hewezi, T. (2014). Proteinprotein interaction and gene co-expression maps of ARFs and Aux/IAAs in Arabidopsis. Front. Plant Sci. 5:744. doi: 10.3389/fpls.2014.00744

Polyn, S., Willems, A., and De Veylder, L. (2015). Cell cycle entry, maintenance, and exit during plant development. Curr. Opin. Plant Biol. 23, 1-7. doi: 10.1016/ j.pbi.2014.09.012

Ponce, G., Barlow, P. W., Feldman, L. J., and Cassab, G. I. (2005). Auxin and ethylene interactions control mitotic activity of the quiescent centre, root cap size, and pattern of cap cell differentiation in maize. Plant Cell Environ. 28, 719-732. doi: 10.1111/j.1365-3040.2005.01318.x

Rademacher, E. H., Möller, B., Lokerse, A. S., Llavata-Peris, C. I., van den Berg, W., and Weijers, D. (2011). A cellular expression map of the Arabidopsis AUXIN RESPONSE FACTOR gene family. Plant J. 68, 597-606. doi: 10.1111/j.1365313X.2011.04710.x

Rahni, R., and Birnbaum, K. D. (2019). Week-long imaging of cell divisions in the Arabidopsis root meristem. Plant Methods 15:30.

Rashotte, A. M., Mason, M. G., Hutchison, C. E., Ferreira, F. J., Schaller, G. E., and Kieber, J. J. (2006). A subset of Arabidopsis AP2 transcription factors mediates cytokinin responses in concert with a two-component pathway. Proc. Natl. Acad. Sci. U.S.A. 103, 11081-11085. doi: 10.1073/pnas.0602038103

Reyes-Hernández, B. J., Shishkova, S., Amir, R., Quintana-Armas, A. X., Napsucialy-Mendivil, S., Cervantes-Gamez, R. G., et al. (2019). Root stem cell niche maintenance and apical meristem activity critically depend on THREONINE SYNTHASE1. J. Exp. Bot. 70, 3835-3849. doi: 10.1093/jxb/ erz165

Reyes-Hernández, B. J., Srivastava, A. C., Ugartechea-Chirino, Y., Shishkova, S., Ramos-Parra, P. A., Lira-Ruan, V., et al. (2014). The root indeterminacyto-determinacy developmental switch is operated through a folate-dependent pathway in Arabidopsis thaliana. New Phytol. 202, 1223-1236. doi: 10.1111/nph. 12757

Rodriguez-Villalon, A., and Hardtke, C. S. (2014). "Auxin and its henchmen: hormonal cross talk in root growth and development," in Auxin and Its Role in Plant Development, eds E. Zažímalová, J. Petrášek, and E. Benková (Vienna: Springer), 245-264. doi: 10.1007/978-3-7091-1526-8_12

Sabatini, S., Beis, D., Wolkenfelt, H., Murfett, J., Guilfoyle, T., Malamy, J., et al. (1999). An auxin-dependent distal organizer of pattern and polarity in the Arabidopsis root. Cell 99, 463-472. doi: 10.1016/S0092-8674(00)81535-4

Sabatini, S., Heidstra, R., Wildwater, M., and Scheres, B. (2003). SCARECROW is involved in positioning the stem cell niche in the Arabidopsis root meristem. Genes Dev. 17, 354-358. doi: 10.1101/gad.252503

Sánchez-Calderón, L., López-Bucio, J., Chacón-López, A., Cruz-Ramírez, A., Nieto-Jacobo, F., Dubrovsky, J. G., et al. (2005). Phosphate starvation induces a determinate developmental program in the roots of Arabidopsis thaliana. Plant Cell Physiol. 46, 174-184. doi: 10.1093/pcp/pci011

Santner, A., Calderon-Villalobos, L. I. A., and Estelle, M. (2009). Plant hormones are versatile chemical regulators of plant growth. Nat. Chem. Biol. 5, 301-307. doi: $10.1038 /$ nchembio. 165

Sarkar, A. K., Luijten, M., Miyashima, S., Lenhard, M., Hashimoto, T., Nakajima, K., et al. (2007). Conserved factors regulate signalling in Arabidopsis thaliana shoot and root stem cell organizers. Nature 446, 811-814. doi: 10.1038/nature05703

Savina, M. S., Pasternak, T., Omelyanchuk, N. A., Novikova, D. D., Palme, K., Mironova, V. V., et al. (2020). Cell dynamics in WOX5-overexpressing root tips: the impact of local auxin biosynthesis. Front. Plant Sci. 11:169. doi: 10.3389/fpls. 2020.560169

Scadden, D. T. (2006). The stem-cell niche as an entity of action. Nature 441, 1075-1079. doi: 10.1038/nature04957

Scheres, B., Di Laurenzio, L., Willemsen, V., Hauser, M. T., Janmaat, K., Weisbeek, P., et al. (1995). Mutations affecting the radial organisation of the Arabidopsis root display specific defects throughout the embryonic axis. Development 121 , 53-62.

Shimotohno, A., Heidstra, R., Blilou, I., and Scheres, B. (2018). Root stem cell niche organizer specification by molecular convergence of PLETHORA and SCARECROW transcription factor modules. Genes Dev. 32, 1085-1100. doi: 10.1101/gad.314096.118

Sozzani, R., Cui, H., Moreno-Risueno, M. A., Busch, W., Van Norman, J. M., Vernoux, T., et al. (2010). Spatiotemporal regulation of cell-cycle genes by SHORTROOT links patterning and growth. Nature 466, 128-132. doi: 10.1038/ nature 09143

Stepanova, A. N., Robertson-Hoyt, J., Yun, J., Benavente, L. M., Xie, D. Y., Doležal, $\mathrm{K}$., et al. (2008). TAA1-mediated auxin biosynthesis is essential for hormone crosstalk and plant development. Cell 133, 177-191. doi: 10.1016/j.cell.2008.01. 047

Su, Y. H., Liu, Y. B., and Zhang, X. S. (2011). Auxin-cytokinin interaction regulates meristem development. Mol. Plant 4, 616-625. doi: 10.1093/mp/ssr007

Swarup, R., Kramer, E. M., Perry, P., Knox, K., Leyser, H. O., Haseloff, J., et al. (2005). Root gravitropism requires lateral root cap and epidermal cells for transport and response to a mobile auxin signal. Nat. Cell Biol. 7, 1057-1065. doi: $10.1038 /$ ncb1316

Takahashi, N., and Umeda, M. (2014). Cytokinins promote onset of endoreplication by controlling cell cycle machinery. Plant Signal. Behav. 9, 1812-1817. doi: 10.4161/psb.29396

Tian, H., Wabnik, K., Niu, T., Li, H., Yu, Q., Pollmann, S., et al. (2014). WOX5IAA17 feedback circuit-mediated cellular auxin response is crucial for the patterning of root stem cell niches in Arabidopsis. Mol. Plant 7, 277-289. doi: $10.1093 / \mathrm{mp} / \mathrm{sst} 118$

Timilsina, R., Kim, J. H., Nam, H. G., and Woo, H. R. (2019). Temporal changes in cell division rate and genotoxic stress tolerance in quiescent center cells of Arabidopsis primary root apical meristem. Sci. Rep. 9, 1-9. doi: 10.1007/97894-010-0936-2_1 
To, J. P., Deruère, J., Maxwell, B. B., Morris, V. F., Hutchison, C. E., Ferreira, F. J., et al. (2007). Cytokinin regulates type-A Arabidopsis response regulator activity and protein stability via two-component phosphorelay. Plant Cell Online 19, 3901-3914. doi: 10.1105/tpc.107.052662

Truskina, J., Han, J., Chrysanthou, E., Galvan-Ampudia, C. S., Lainé, S., Brunoud, G., et al. (2020). A network of transcriptional repressors modulates auxin responses. Nature 589, 116-119. doi: 10.1038/s41586-020-2940-2

Tsukagoshi, H., Busch, W., and Benfey, P. N. (2010). Transcriptional regulation of ROS controls transition from proliferation to differentiation in the root. Cell 143, 606-616. doi: 10.1016/j.cell.2010.10.020

Ubeda-Tomás, S., Federici, F., Casimiro, I., Beemster, G. T., Bhalerao, R., Swarup, R., et al. (2009). Gibberellin signaling in the endodermis controls Arabidopsis root meristem size. Curr. Biol. 19, 1194-1199. doi: 10.1016/j.cub.2009.06.023

Ueda, M., Matsui, K., Ishiguro, S., Sano, R., Wada, T., Paponov, I., et al. (2004). The HALTED ROOT gene encoding the 26S proteasome subunit RPT2a is essential for the maintenance of Arabidopsis meristems. Development 131, 2101-2111. doi: 10.1242/dev.01096

Ulmasov, T., Hagen, G., and Guilfoyle, T. J. (1999). Activation and repression of transcription by auxin-response factors. Proc. Natl. Acad. Sci. U.S.A. 96, 5844-5849. doi: 10.1073/pnas.96.10.5844

Ulmasov, T., Murfett, J., Hagen, G., and Guilfoyle, T. J. (1997). Aux/IAA proteins repress expression of reporter genes containing natural and highly active synthetic auxin response elements. Plant Cell 9, 1963-1971. doi: 10.1105/tpc. 9.11.1963

van den Berg, C., Willemsen, V., Hage, W., Weisbeek, P., and Scheres, B. (1995). Cell fate in the Arabidopsis root meristem determined by directional signalling. Nature 378, 62-65. doi: 10.1038/378062a0

van den Berg, C., Willemsen, V., Hendriks, G., Weisbeek, P., and Scheres, B. (1997). Short-range control of cell differentiation in the Arabidopsis root meristem. Nature 390, 287-289. doi: 10.1038/36856

van Esse, G. W., Westphal, A. H., Surendran, R. P., Albrecht, C., van Veen, B., Borst, J. W., et al. (2011). Quantification of the brassinosteroid insensitivel receptor in planta. Plant Physiol. 156, 1691-1700. doi: 10.1104/pp.111.179309

Vanneste, S., and Friml, J. (2009). Auxin: a trigger for change in plant development. Cell 136, 1005-1016. doi: 10.1016/j.cell.2009.03.001

Vanstraelen, M., Baloban, M., Da Ines, O., Cultrone, A., Lammens, T., Boudolf, V., et al. (2009). APC/CCCS52A complexes control meristem maintenance in the Arabidopsis root. Proc. Natl. Acad. Sci. U.S.A. 106, 11806-11811. doi: 10.1073/pnas.0901193106

Vernoux, T., Brunoud, G., Farcot, E., Morin, V., Van den Daele, H., Legrand, J., et al. (2011). The auxin signalling network translates dynamic input into robust patterning at the shoot apex. Mol. Syst. Biol. 7:508. doi: 10.1038/msb.2011.39

Vernoux, T., Wilson, R. C., Seeley, K. A., Reichheld, J. P., Muroy, S., Brown, S., et al. (2000). The ROOT MERISTEMLESS1/CADMIUM SENSITIVE2 gene defines a glutathione-dependent pathway involved in initiation and maintenance of cell division during postembryonic root development. Plant Cell 12, 97-109. doi: $10.1105 /$ tpc.12.1.97

Vilarrasa-Blasi, J., González-García, M. P., Frigola, D., Fàbregas, N., Alexiou, K. G., López-Bigas, N., et al. (2014). Regulation of plant stem cell quiescence by a brassinosteroid signaling module. Dev. Cell 30, 36-47. doi: 10.1016/j.devcel. 2014.05.020

Vragović, K., Sela, A., Friedlander-Shani, L., Fridman, Y., Hacham, Y., Holland, N., et al. (2015). Translatome analyses capture of opposing tissue-specific brassinosteroid signals orchestrating root meristem differentiation. Proc. Natl. Acad. Sci. U.S.A. 112, 923-928. doi: 10.1073/pnas.1417947112

Wachsman, G., Heidstra, R., and Scheres, B. (2011). Distinct cell-autonomous functions of RETINOBLASTOMA-RELATED in Arabidopsis stem cells revealed by the brother of brainbow clonal analysis system. Plant Cell 23, 2581-2591. doi: 10.1105/tpc.111.086199
Wang, Z., Rong, D., Chen, D., Xiao, Y., Liu, R., Wu, S., et al. (2020). Salicylic acid promotes quiescent center cell division through ROS accumulation and downregulation of PLT1, PLT2, and WOX5. J. Integr. Plant Biol. doi: 10.1111/jipb. 13020. [Epub ahead of print].

Welch, D., Hassan, H., Blilou, I., Immink, R., Heidstra, R., and Scheres, B. (2007). Arabidopsis JACKDAW and MAGPIE zinc finger proteins delimit asymmetric cell division and stabilize tissue boundaries by restricting SHORT-ROOT action. Genes Dev. 21, 2196-2204. doi: 10.1101/gad.440307

Wildwater, M., Campilho, A., Perez-Perez, J. M., Heidstra, R., Blilou, I., Korthout, H., et al. (2005). The RETINOBLASTOMA-RELATED gene regulates stem cell maintenance in Arabidopsis roots. Cell 123, 1337-1349. doi: 10.1016/j.cell.2005. 09.042

Xu, T., Calderon-Villalobos, L. I. A., Michal, S., Zheng, C., Robinson, C. V., Estelle, M., et al. (2007). Mechanism of auxin perception by the TIR1 ubiquitin ligase. Nature 446, 640-645. doi: 10.1038/nature05731

Yu, Q., Tian, H., Yue, K., Liu, J., Zhang, B., Li, X., et al. (2016). A P-loop NTPase regulates quiescent center cell division and distal stem cell identity through the regulation of ROS homeostasis in Arabidopsis root. PLoS Genet. 12:e1006175. doi: 10.1371/journal.pgen.1006175

Zhai, H., Zhang, X., You, Y., Lin, L., Zhou, W., and Li, C. (2020). SEUSS integrates transcriptional and epigenetic control of root stem cell organizer specification. EMBO J. 39:e105047. doi: 10.15252/embj.2020105047

Zhang, H., Han, W., De Smet, I., Talboys, P., Loya, R., Hassan, A., et al. (2010). ABA promotes quiescence of the quiescent centre and suppresses stem cell differentiation in the Arabidopsis primary root meristem. Plant J. 64, 764-774. doi: 10.1111/j.1365-313X.2010.04367.x

Zhang, W., Swarup, R., Bennett, M., Schaller, G. E., and Kieber, J. J. (2013). Cytokinin induces cell division in the quiescent center of the Arabidopsis root apical meristem. Curr. Biol. 23, 1979-1989. doi: 10.1016/j.cub.2013.08.008

Zhang, W., To, J. P., Cheng, C. Y., Eric Schaller, G., and Kieber, J. J. (2011). TypeA response regulators are required for proper root apical meristem function through post-transcriptional regulation of PIN auxin efflux carriers. Plant J. 68, 1-10. doi: 10.1111/j.1365-313X.2011.04668

Zhang, Y., Jiao, Y., Liu, Z., and Zhu, Y. X. (2015). ROW1 maintains quiescent centre identity by confining WOX5 expression to specific cells. Nat. Commun. 6:6003. doi: 10.1038/ncomms7003

Zhou, W., Lozano-Torres, J. L., Blilou, I., Zhang, X., Zhai, Q., Smant, G., et al. (2019). A jasmonate signaling network activates root stem cells and promotes regeneration. Cell 177, 942-956. doi: 10.1016/j.cell.2019.03.006

Zhu, J. Y., Sae-Seaw, J., and Wang, Z. Y. (2013). Brassinosteroid signalling. Development 140, 1615-1620. doi: 10.1242/dev.060590

Zürcher, E., Tavor-Deslex, D., Lituiev, D., Enkerli, K., Tarr, P. T., and Müller, B. (2013). A robust and sensitive synthetic sensor to monitor the transcriptional output of the cytokinin signaling network in planta. Plant Physiol. 161, 10661075. doi: 10.1104/pp.112.211763

Conflict of Interest: The authors declare that the research was conducted in the absence of any commercial or financial relationships that could be construed as a potential conflict of interest.

Copyright (c) 2021 García-Gómez, Garay-Arroyo, García-Ponce, Sánchez and Álvarez-Buylla. This is an open-access article distributed under the terms of the Creative Commons Attribution License (CC BY). The use, distribution or reproduction in other forums is permitted, provided the original author(s) and the copyright owner(s) are credited and that the original publication in this journal is cited, in accordance with accepted academic practice. No use, distribution or reproduction is permitted which does not comply with these terms. 